Jurnal Konstruksi Hukum | ISSN: 2746-5055

Vol. 2, No. 2, Mei 2021, Hal. 218-222| Tersedia online di

https://www.ejournal.warmadewa.ac.id/index.php/jukonhum

DOI: https://doi.org/10.22225/jkh.2.2.3209.218-222

\title{
PENYELESAIAN SENGKETA TRANSAKSI BISNIS ELEKTRONIC COMMERCE MELALUI INTERNET
}

\author{
Anak Agung Bagus Sempidi Junior, Anak Agung Sagung Laksmi Dewi, Desak Gde Dwi Arini \\ Fakultas Hukum, Universitas Warmadewa, Denpasar - Bali, Indonesia \\ ajusjrll@gmail.com, laksmidewi2909@gmail.com, arinidesak1966@gmail.com
}

\begin{abstract}
Pengembangan Teknologi informasi melalui infrastruktur hokum dan pengaturannya sehingga pemanfaatan Teknologi lnformasi dilakukan secara aman untuk mencegah penyalahgunaannya dengan memperhatikan nilainilai agama dan sosial budaya masyarakat Lndonesia. Metode penelitian menggunakan penelitian hukum normatif dan pendekatan masalah menggunakan pendekatan perundang- undangan dan konseptual. Hasil penelitian mengatakan bahwa perlindungan hukum konsumen dalam transaksi bisnis Electronic Commerce melalui online diatur melalui pejanjian jual beli online berdasarkan syarat formil dan materiil secara konvensional telah didampingi dengan transaksi jual beli yang dilakukan secara elektronik melalui media komputer. Penyelesaian sengketa dalam transaksi bisnis e-commerce melalui online, dilakukan baik secara non litigasi maupun litigasi. Adapun sarannya adalah kepada Pemerintah, dinarapkan keikutan sertaan penyelesaian permasalahan sangat penting, apabila terjadi kasus seperti ini antar Negara yang berbeda, maka penyelesaian rnasalah ini harus ditentukan aturan hukum yang mana akan digunakan untuk menyelesaiakannya. Tujuan dari penelitian ini untuk mengetahui perlindungan hukum bagi konsumen dalam transaksi bisnis electronic comerce melalui online, dan bagaimana penyelesaian sengketa yang terjadi dalam perjanjian transaksi bisnis elektronic commercemalalui online.
\end{abstract}

Kata Kunci: Penyelesaian Sengketa, Transaksi, Electronic.

\begin{abstract}
Development of information technology through legal infrastructure and its regulation so that the use of Information Technology is carried out safely to prevent its misuse by taking into account the religious and socio-cultural values of the Indonesian people. . The research method uses normative legal research and problem approaches using statutory and conceptual approaches. The results of the study show that consumer legal protection in online Electronic Commerce business transactions is regulated through online sale and purchase agreements based on conventional formal and material terms accompanied by buying and selling transactions carried out electronically through computer media. Settlement of disputes in e-commerce business transactions via online, is carried out both non-litigation and litigation. The suggestion is to the Government, it is hoped that participation in solving problems is very important, if a case like this occurs between different countries, then the settlement of this problem must be determined which legal rules will be used to solve it. The purpose of this study is to determine legal protection for consumers in electronic commerce business transactions through online, and how to resolve disputes that occur in electronic commerce business transaction agreements through online.
\end{abstract}

Keywords: Dispute Resolution, Transaction, Electronic.

\section{PENDAhuluan}

Kemajuan pengetahuan serta ilmu teknologi meliputi diantaranya merebak luasnya dunia maya yang familiar disebut online. Dengan cara online mempermudah seseorang melakukan berbagai aktivitas yang tidak hanya pada ruang lingkup nasional serta local akan tetapi meliputi secara global serta memungkinkan menjamah sampai ruang lingkup intemasional. Memungkinkan bahwasannya kegiatan melalui media internet itu merupakan aktivitas yang tidak terbatas, dengan demikian artiannya adalah mempermudah berhubungan dengan siapapun, dimanapun serta kapanpunjuga (Subekti, 2002:56). Teknologi informasi memiliki peran yang sangat strategis karena menghadirkan suatu dunia tanpa adanya batasan jarak, ruang, waktu dan dapat meningkatkan kinerja manusia dalam berbagai kegiatan sehingga memberikan dampak terhadap peningkatan produktivitas dan efisiensi (Sunarso, 2009). Saat ini, instrumen hukum di Indonesia belum memberikan perlindungan hukum yang lengkap bagi konsumen dalam transaksi e-commerce. Mekanisme penyelesaian sengketa yang tersedia adalah melalui pengadilan dan di luar pengadilan (Setiantoro dkk, 2018). Penting kiranya dalah hal ini 
menumbuhkan sikap yang selektif dan cermat dalam menghadapi perubahan paradigm pola hukum yang berkaitan dengan aktivitas penjualan serta pembelian melalui media online. Peran serta pemerintahan secara tegas mengeluarkan konstitusi berupa UU Nomor 11 Tahun 2008 tentang Informasi dan Transaksi Elektronik (selanjutnya disebut UU ITE), mempertimbangkan pembangunan jangka nasional merupakan proses berkelanjutan yang dengan senantiasa memperhatikan berbagai problematika yang ada pada masyarakat.

Mengenai Penilaian Ahli adalah prosedur atau proses penyelesaian sengketa atau perselisihan dengan meminta pendapat yang dimiliki oleh para ahli dan akan digunakan sebagai solusi untuk menyelesaian sengketa atau perselisihan tersebut (Rahmadi,2011). Kajian tentang transaksi dan perdagangan, baik melalui media elektronik maupun non-elektroniktelah sering mendominasi kajian ilmiah terhadap dunia bisnis. Dalam hal penyelesaian sengketa dalam ecommerce, sengketa yang melibatkan $e$-banking dan perselisihan dokumen perusahaan yang telahditransfer dalam bentuk media elektronik dapat diajukan dengan alat bukti dalam bentuk alat bukttertulis, saksi mata, presuposisi, pengakuan, sumpah, dan saksi mata ahli untuk memperkuat dokumenelektronik. Namun demikian, aturan hukum belum diberikan secara komprehensif (Bintoro, 2011). Dalam perspektif yuridis dasar penyelesaian kasus-kasus transaksi elektronik menjadi penguatan hukum untuk mengambil rasa keadilan sehingga dapat dilihat bahwa dasar pengaturan e-commerce internasional sesuai dengan Pasal 18 Ayat (4) dari UU ITE dan Pengadilan Negeri memiliki peran sebagai institusi utama dan pelengkap dalam penyelesaian sengketa. transaksi elektronik internasional (Ayu,2018).

Permasalahan urgensi masalah globalisasi informasi telah meletakkan pandangan bahwa negara Indonesia menjadi bagian daripada masyarakat dunia, maka memberikan keharusan adanya pengaturan tentang pengelolaan informasi dan transaksi elektronik di tingkat nasional. Dengan demikian terciptanya pembangunan teknologi maupun informasia yang secara optimal, merata, serta dapat menjamah seluruh basis masyarakat untuk mencerdaskan aspek kehidupan bangsa. Seyogianya penggunaan serta memanfaatkan LPTEK seharusnya secara terus menerus dapat dilimpah luaskan guna memproteksi dan memelihara, serta dapat memperkuat dan memperkokoh persatuan kesatuan nasional yang berlandaskan atas konstitusional demi kepentingan nasional seutuhnya.

Berdasarkan uraian permasalahan yang telah penulis kemukakan diatas, maka dapat ditarik rumusan-rumusan permasalahan pokok diantaranya yaitu:

1. Bagaimanakah perlindungan hukum bagi konsumen dalam transaksi bisnis electronic comerce melalui online?

2. Bagaimana penyelesaian sengketa yang terjadi dalam perjanjian transaksi bisnis elektronic commerce malalui online?

Sehingga, tujuan daripada penelitian ini antara lain:

1. Untuk mengetahui perlindungan hukum bagi konsumen dalam transaksi bisnis electronic comerce melalui online.

2. Untuk mengetahui penyelesaian sengketa yang terjadi dalarn perjanjian transaksi bisnis elektronic commerce malalui online.

\section{METODE PENELITIAN}

Tipe penelitian ini merupakan penelitian hukum normatif, yaitu dengan melakukan kajian permasalahan yang dibahas berdasarkan norma perundang-undangan yang berlaku dengan perjanjian jual beli melalui online. Dalam rangka menyusun penulisan ini, pendekatan masalah yang diambil adalah pendekatan masalah secara normatif dengan pendekatan konseptual dan perundang-undangan. Surnber bahan hukum terdiri dari Bahan hukum primer, yaitu bahan-bahan hukum yang mempunyai kekuatan mengikat, terdiri atas peraturan perundang-undangan. Adapun peraturan perundangundangan yang digunakan diantaranya : UUD NRI 1945, KUHPerdata, UU Nomor 36 Tahun 1999 tentang Telekomunikasi, dan UU Nomor 8 Tahun 1999 tentang Perlindungan Konsumen, UU Nomor 11 Tahun 2008 tentang lnformasi dan Transaksi Elektronik. Serta bahan hukum sekunder yang terdiri atas hasil karya ilmiah para sarjana, artikel, file elektronik, website, buku-buku yang berhubungan dengan pokok permasalahan dalam penelitian ini. Selanjutnya bahan hukum Tersier adalah yang memberikan petunjuk maupun penjelasan terhadap bahan hukum primer dan sekunder, yaitu kamus hukum. 


\section{HASIL DAN PEMBAHASAN}

\section{Perlindungan Hukum Bagi Konsumen Dalam Transaksi Bisnis Electronic Comerce Melalui Online}

Inti perihal pokok yang dilaksanakan dalam kegiatan e-commerce merupakan transaksi jual beli diantaranya meliputi pihak penjual serta pembeli yang dilaksanakan bebas dari unsur paksaan, serta dinyatakan dengan sah berdasarkan ketentuan hukum yang masih berkaitan. Dalam UUPK memuatkan bahwasannya bentuk perlindungan konsumen merupakan upaya yang memberikan jaminan atas kepastian hukum guna memberikan perlindungan pada konsumen. (Maman Suherman, 2002:70). Dalam aktivitasnya transaksi e-commerce dapat dilaksanakan baik secara online, berawal dari proses terjadinya transaksi sampai pada pembayaran, dengan demikian pihak yang terlibat dapat terdiri atas : (Abdul Halim dan Teguh Prasetyo, 2006:26)

1. Penjual (merchant), yaitu produsen ataupun perusahaan produsen yang memperkenalkan produknya melalui media on line.

2. Konsumen ( card holder), merupakan orang-orang yang memiliki keinginan mendapatkan barang atau jasa dengan cara pembelian lewat media online.

3.Pihak perantara (Acquirer), merupakan perantara penagihan antara penerbit dan penjual, serta perantara pembayaran diantara penerbit dan pemegang.

4. Issuer: perusahaan yang menerbitkan kartu kredit.

Serta didalamnya terlibat Certification Authorities yang merupakan pihak ketiga secara netralitas memegang hak mengeluarkan sertifikasi kepada penjual, kepada issuer serta beberapa hal diserahkan pula kepada konsumen. Perikatan dalam arti sederhana, merupakan perikatan yang para pihak hanya terdapat satu orang serta satu prestasi yang seketika itu juga dapat dilakukannya penagihan pembayarannya.(Subekti, 1985: 128)

Syarat sahnya perjanjian secara formil tertuang pada ketentuan Pasal 1320 KUHPerdata yang secara singkat memuatkan unsur kesepakatan, kecakapan hukum, suatu pokok tertentu, serta objek perjanjian yang jelas dan halal. Pasal 1320 KUHPerdata tidak memuatkan dalam perjanjian secara rincinya harus menggunakan media apapun dalam bertransaksi. Dengan demikian, tentu sah saja dilakukannya perjanjian secara langsung ataupun secara elektronik. Akan tetapi, justru suatu keharusan bahwa perjanjian dikatakan sah apabila sepenuhnya telah terpenuhinya semua unsur sebagaimana termuat dalam ketentuan pasal tersebut.

Selain itu asas perjanjian juga mengenal asas kebebasan berkontrak, yang secara hukum perdata, para pihak diberikan kebebasan untuk menentukan perikatan atau perjanjian itu dengan subjek ataupun objek perjanjian selama dilakukan dengan itikhad baik. Berupa bentuk apapun perjanjian itu akan mengikat satu sama lainnya dan menjadi undang-undang bagi para pihak yang membuat perjanj ian iru (pacta sun/ servada). Sehingga permasalahan-permasalahan yang kemudian hari timbul akibat wanprestasi baik itu dalam transaksi elektronik akan menjadi permasalahan baru, mengingat dalam hukum acara perdata belum diatur khusus mengenai

penyelesaian sengketa tersebut, namun tidak menutup kemungkinan dapat ditangani berdasarkan kajian-kajian yang lebih spesifik.

\section{Penyelesaian Sengketa yang Terjadi dalam Perjanjian Transaksi Bisnis Electric Comerce Melalui Online}

Penyelesaian Sengketa Diluar Pengadilan/ Non Litigasi Permasalahan hukum berupa sengketa ataupun konflik hukum pada aspek universal dipicu dengan timbulnya perbedaan ataupun perselisihan yang jauh tidak sesuai ataupun keliru antara pihak-pihak. Kadangkala para pihak sulit berhasil mendapatkan bentuk penyelesaian yang cocok, sehingga timbullah perbedaan pendapat yang berakibat buruk bagi kesejahteraan di antara kedua belah pihak itu. Oleh sebab iru, perbedaan pendapat yang menimbulkan sengketa, musti berusaha bagi setiap pihak untuk menemukan solusi yang tepat. Awal mulanya bentuk-bentuk penyelesaian yang digunakan berporos pada bagaimana mendapatkan keuntungan dari permasalahan itu. Maka karenanya keuntungan dijadikan tujuan utama, setiap pihak memiliki kecenderungan berusaha memakai segala cara untuk meraih keuntungan itu, meskipun dengan cara melanggar norma. Tindakan tersebut justru merusak hubungan diantara pihak yang bersengketa menjadi buruk, serta bahkan menjadi permusuhan.( Soerjono Soekanto dan Sri Mamudji, 1984:39) 
Cita-cita berdirinya suatu Negara Kesatuan Republik Indonesia untuk membentuk Negara Hukum (rechtstaaty, dengan itulah parameter pencapaiannya yaitu membentuk situasi serta kondisi maupun kesanggupan warga negara untuk mematuhi hukum, bahkan dalarn kondisi itu, pelaksanaan penegakan hukum sepenuhnya dilaksanakan mempergunakan persfektif keadilan yang formal, yang berbentuk tindakan represif serta dilanjutkannya melalui proses hukum litigasi. Dengan dasar itulah, tindakan litigatifformal banyak ketergantungan dengan upaya memaksa kewenangan petugas hukum. Mulailah muncul suatu hasil, pada

umumnya berakhir dengan kondisi serta siruasi "sama kalah" ataupun " antara kemenangan dan kekalahan".

Seyogianya, masih jauh untuk memberikan pemyataan yang sebaliknya, masih seringkali dilaksanakannya suatu proses penegakan hukurn litigasi. Faktanya, di situasi dalam negara kalaupun dilaksanakannya bentuk proses penegakan hukurn terhadap suatu tindakan melanggar hukum, yang seringkali terjadi merupakan suatu bentuk dan hanya merupakan tindakan formal hukum ataupun mengesampingkan hukum. Tindakan tersebut secara substansi merupakan kooptasi yang besar terhadap elemen negara pada bidang hukum, contoh jelas ialah terhadap peradilan, dengan itu berhasil menciprakan putusan yang bias dan diskriminatif namun malah memungkinkan timbulnya ketidak adilan.Bentuk penyelesaian yang dilandaskan atas kuntungan dan kemenangan tidak menjadi pilihan utama seiring dengan perkembangannya, lebih-lebih kemungkinannya dihindari. Setiap pihak mernilih memprioritaskan komprorni dan musyawarah untuk menyelesaikan sengketa yang tercipta, dengan penuh keinginan melalui kompromi, pihak yang merasa dikalahkan ataupun dirugikan dapat menerima dengan baik, sehingga rasa persatuan kekeluargaan bisa terjalin. Berbicara mengenai hukum dan lembaga negara dalam rugas pokoknya melaksanakan penegakan hukurn, terdapat rangkaian yang mengkaitkannya dengan isu tentang formal justice yang diciptakan melalui hukum ataupun proses hokum yang formal. Dikatakan formal, dengan makna mengingat suatu hukum yang dilaksanakan oleh negara di lembaga bidang hukum dilandaskan kepada hukum berbentuk tertulis dan dikodifikasikan, dilaksanakan oleh aparat berwenang dengan dasar kewenangan, serta memerlukan proses hukum acara yang juga merupakan standar dan kekal.

Akan tetapi demikian, sisi lain daripada hukum serta proses yang formal tersebutlah, terdapat akan fakta mengenai keadilan formal itu, sekurangnya di negara Indonesia, ternyata tidak murah, terlalu Jama, membosankan, tidak menemukan solusi masalah dan yang lebih mengesankan, masih banyak terdapat indikasi korupsi, kolusi dan nepotisme. Diantaranya dari berbagai problematika itu membentuk keadilan ini terlihat begiru problematik, rnengingat dilakukannya salah satu upaya yang sama untuk segala jenis masalah (one for all mechanism). Hal inilah yang menimbulkan akibat dari awal mulanya dan berpalingnya setiap pihak unruk rnencari kemungkinan lain atas penyelesaian masalah. Penyelesaian Sengketa Di Dalam Pengadilan/Litigasi. Fakta atas suatu komentar dan masukan yang rnenganggap masih mahalnya biaya perkara justru rnemberikan pengaruh terhadap perkembangan ekonomi yang tidak hanya terjadi di negara Arnerika, namun juga terjadi pada semua negara. Masukan kritik terganrung dari berbagai negara yang dirangkum sebagai berikut:

1. Kurang cepatnya proses penyelesaian sengketa.

Menyelesaikan sengketa lewat jalur litigasi pada intinya yaitu membuang waktu (waste of time).

Proses dalam pemeriksaan terlalu fonnalistis serta bersifat teknis. Pada sisi lain, alur sengketa semakin kompleks, hal ini memungkinkan lembaga peradilan dituntut dengan tanggung jawab yang terlampau banyak (overloaded). Bukan hanya untuk memperoleh suatu putusan yang berkekuatan hukum. Justru dalam hal memulai proses pemeriksaan, malahan mengharuskan untuk menunggu dan mengantri.

2. Biaya perkara yang tidak terjangkau.

Setiap pihak rnemberikan opini mengenai biaya perkara yang sangat mahal, terlebih lagi dikaitkaitkan dengan lamanya waktu proses penanganan sengketa. Apalagi proses yang lama suatu perkara ataupun sengketa justru akan makin besar pembiayaan yang dikeluarkan. Setiap pihak mengeluh berperkara di pengadilan musti menjadi keharusan mengorbankan semua sumber daya, waktu, tenaga serta pikiran.

3. Lembaga hukum kurang tanggap.

Lembaga pengadilan masih dianggap belum tanggap dan kurang responsif dalam melaksanakan rugas pokoknya sebagai lembaha keadilan. Ketidaknyamanan ini tentu dikarenakan pengadilan kurang tanggap rnembela serta memberikan 
perlindungan akan kepentingan suatu kebutuhan pihak yang berkepentingan dan urnum ataupun masyarakatjustru mengecam lembaga pengadilan seringkali belum mampu berlaku dengan adil.

4. Pengadilan dengan putusannya belum mampu menyelesaikan masalah. Putusan dari pengadilan belum mampu memberikan penyelesaian yang akurat kepada para pihak. Putusan pengadilan belum mampu memberikan kesejahteraan dan kedamaian kepada pihak pencari keadilan.

Suatu pandangan dan pendapat yang ditujukan kepada lembaga Pengadilan keseluruhannya bukan hanya di Indonesia, namunjuga untuk segelintirnegara yang industrinya maju. Justru perkembangan masyarakat yang lebih mendorong percepatan, perihal rahasia, efisiensi serta efektifitas untuk menjaga keberlangsungan ikatan yang telah ada, belum dapat menciptakan win-win solution dan menginginkan penyelesaian yang jauh Jebih menekankan pada aspek keadilan seperti halnya prinsip penyelesaian sengketa yang lebih sederhana dan mendapatkan pandangan yang lebih baik, terutama dalam bisnis

\section{IV .SIMPULAN DAN SARAN}

\section{Simpulan}

Perlindungan hukum konsumen dalam transaksi bisnis Electronic Commerce melalui online diatur melalui pejanjian jual beli online berdasarkan syarat formil dan materiil. Masih ada keterkaitan dengan syarat legalnya suatu perjanjian. Dikarenakan olehnya belum adanya aturan khusus tentang penanganan hal ini, karena itulah pengaturan masih didasarkan pada B uku Ill KUHPerdata, serta unsur-unsur dalam muatan tersebut telah sesuai dalam transaksi e-commerce melalui deskripsi yang telah diungkapkan. Penyele aian sengketa dalam transaksi bisnis e-commerce melalui online, dilakukan baik secara non litigasi maupun litigasi, penyelesaian yang baik adalah secara non litigasi yairu dengan cara perundingan/mediasi, karena dengan cara tersebut masing-masing pihak tidak adayang merasa dikalahkan dalam sengketa tersebut dan waktu dibutuhkan tidaklah lama dan uang yang dikeluarkan tidak.

\section{Saran}

Berdasarkan simpulan tersebut diatas, dapat dikemukakan bahwa: masyarakat selaku konsumen, dalam melakukan perjanjian melalui online sebaiknya para konsumen harus lebih waspada agar tidak terjerumus kasus penipuan yang marak terjadi sekarang ini. Kepada pemerintah, diharapkan keikutan sertaan penyelesaiaan masalah ini harus ditentukan aturan hokum yang mana akan digunakan untuk menyelesaikan.

\section{DAFTAR PUSTAKA}

Ayu, I. K. (2018). Peran Pengadilan Negeri Indonesia dalam Penyelesaian Sengketa Transaksi Elektronik Internasional. Legality, 26(1), 40-52.

Bintoro, R. W. (2011). Peradilan, Penerapan Hukum dalam Penyelesaian Sengketa Transaksi Elektronik di Umum. Dinamika Hukum, 11(2), 258-272.

Halim, A., \& Prasetyo, T. (20006). Bisnis £-Commerce. Belajar Pustaka.

Mamudji, S. S. S. (1984). Pengantar Penelitian Hukum. UI Press.

Made, N., \& Ujianti, S. (2020). Penegakan hukum dalam penyelesaian sengketa transaksi. Jurnal Interoretasi Hukum, 1(1), 173-178.

Rahmadi, T. (2011). Mediasi Penyelesaian Sengketa Melalui Pendekatan Mufakat. Rajawali Pers. Suherman, M. (2002). Aspek Hukum Da/am ekonomi Global. Ghaliah Indonesia.

Subekti. (2002). Hukum Perjanjian. Intermasa.

Subekti. (1985). Pokok-Pokok Hukum Perdata. PT. I ntermasa.

Setiantoro, A., Putri, F. D., Novitarani, A., \& Njatrijani, R. (2018). Urgensi Perlindungan Hukum Konsumen dan Penyelesaian Sengketa E-Commerce di Era Masyarakat Ekonomi ASEAN. In V. Wijaya \& E. W. Setyawat (Eds.), Peran Lembaga Peradilan dan Lembaga Alternatif Penyelesaian Sengketa dalam Mendukung Pembangunan Ekonomi Nasion. Jurnal Rechtsvinding., 7(1), 1-17.

Sunarso, S. (2009). Hukum Informasi dan Transaksi Elektronik: Studi Kasus Prita Mulyasari. Rineka Cipta, Jakarta.

Zaeni, A. (2008). Hukum Bisnis. Raja Grafindo. 